\title{
Understanding Quality of Learning in Digital Learning Environments: State of the Art and Research Needed
}

\author{
Bernadette Charlier, Laurent Cosnefroy, Annie Jézégou \\ and Geneviève Lameul
}

\section{Introduction: Towards a Theoretical Framework to Understand Teaching and Learning in $\mathrm{HE}^{1}$}

Over the last two years, the press, blogs and social networks have heralded a tsunami by Massive Open Online Courses ${ }^{2}$ in Higher Education (Cisel and Bruillard 2013; Daniel 2012; Grover et al. 2013). Many universities and colleges in the United States, Europe and also in Switzerland are providing such courses. For a longer period, since the generalization of Learning Management Systems in most universities, teachers have progressively organized and taken into account distance activities alongside face-to-face activities, to the extent that traditional learning

\footnotetext{
${ }^{1}$ This framework has been developed for the submission of a research proposal submitted in April 2014 to the FNS (Swiss) and to ANR (France): the INTENS project.

${ }^{2}$ Today, policy makers have rapidly committed their institutions to new educational projects (since January 2014, 21 MOOCs have been offered in France by the major schools and universities under the banner of France Digital University. In Switzerland, 21 MOOCs are proposed by the EPFL, 3 by the University of Lausanne as of September 2014, and five by the University of Geneva. Data from March 2014.).
}

B. Charlier $(\bowtie)$

University of Fribourg, Fribourg, Switzerland

e-mail: bernadette.charlier@unifr.ch

L. Cosnefroy

Ecole Normale Supérieure Lyon, Lyon, France

e-mail: laurent.cosnefroy@ens-lyon.fr

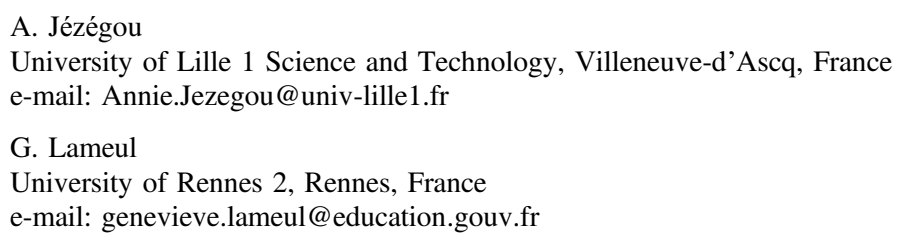


courses are often called 'hybrid' or 'blended learning' courses (Charlier et al. 2006a).

Faced with these changes, actors can rarely call upon research that goes beyond feedback from experience, case studies or satisfaction surveys to guide their action (Deschryver 2008). However, existing research in educational technology, cognitive psychology, adult education and university education, if they are considered together, provide a potentially relevant theoretical and methodological framework to answer the two fundamental research questions:

- How do student characteristics and those of digital learning environments interact?

- What are the configurations emerging from these interactions that can lead to quality learning?

These research questions reflect a systemic perspective in which human learning is part of a circular causality system between three sets of characteristics (Fig. 1): (1) relating to individual students, (2) relating to the digital learning environment, and (3) resulting from the interaction between the two. These so-called 'process' features generate learning outcomes (4) that in turn influence individual and environmental characteristics.

This perspective reflects a circular (i.e. non-linear) systemic model of learning developed by social-cognitive learning theory (Bandura 1986); (Zimmerman 2002). This theory sets the act of learning in a system of reciprocal causality between personal characteristics (cognitive, emotional, and biological, i.e. unique to each learner) and environmental factors (organizational, human, cultural, material, etc.). Such circular causality models, now widely recognized in Adult Education (Cross 1981) and in higher education studies (Tinto 1975), (Biggs 2003), should necessarily guide research methods aimed at understanding the effects of digital learning environments (characterized and differentiated) on the learning of individuals. In what follows, we briefly summarize recent research results that could lay the foundations for this research.

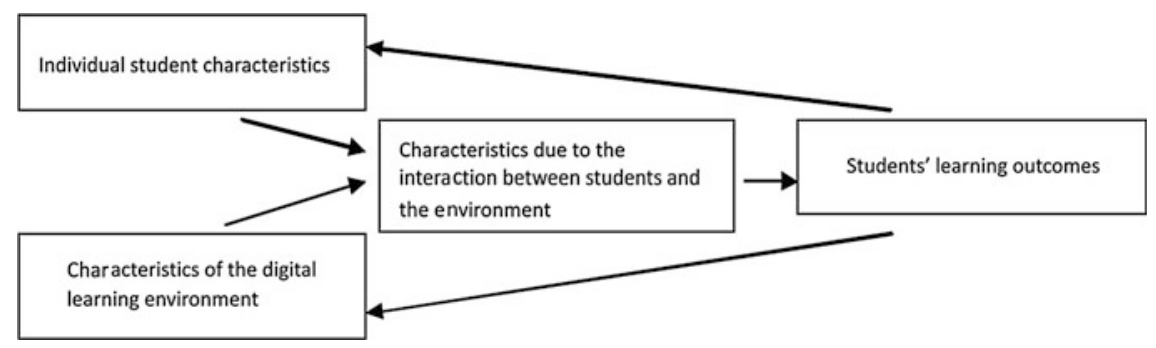

Fig. 1 Systemic perspective of circular causality as proposed by INTENS 


\section{Describing and Understanding the Role of Student Characteristics}

Several studies have analysed the impact of student characteristics on success in higher education. The most studied variables are: (1) Cognitive skills, (2) Academic past, (3) Initial level of knowledge related to the domain that is the subject of learning, (4) Conceptions of knowledge and learning and (5) Personality characteristics.

(1) Cognitive skills. In France, (Morlaix and Suchaut 2012) studied the impact of information processing speed, working memory and inductive reasoning on the average score in the first year of studies, at the end of the first semester and at the end of the academic year. Noting that these variables do not have a direct impact, the authors concluded that their effect was probably felt earlier by contributing to the quality of prior schooling.

(2) Academic past. In the research conducted in the United States, the high school Grade Point Average (GPA) is an important predictor of success at university (Richardson et al. 2012). In the United Kingdom, A-level examinations are also predictors of success at university (Peers and Johnston 1994). In France, getting the baccalauréat and the marks obtained significantly predict success in the first year of university (Morlaix and Suchaut 2012). The same observation has been made in Switzerland (Atzamba and Petroff 2003).

(3) Initial level of knowledge related to the domain that is the subject of learning had an impact on the quality of learning achieved through both cognitive and motivational mechanisms. Cognitively, deep-learning strategies only proved effective if based on sufficiently robust knowledge (Bell and Kozlowski 2002). On a motivational level, (Hidi and Renninger 2006) and (Renninger et al. 2012) hypothesized that the development of structured knowledge in long-term memory, based on a given topic would promote further development of interest in the subject.

(4) Conceptions of knowledge and learning (4.1) Conceptions of learning must be distinguished from approaches to learning. The latter concern student activities in a situation, and as such are considered products of student-environment interactions (Entwistle and McCune 2004; Entwistle 2009). Conceptions of learning, in contrast, refer to different representations of what it means to learn. Marton et al. (1993) proposed a typology of these conceptions ranging from learning as acquiring knowledge to learning as self-transformation. Conceptions of learning influence learning approaches, that is to say, the strategies actually implemented in a situation, but consonance between the two levels is far from complete. Dissonant patterns appear frequently, especially a so-called positive dissonance combining a conception of learning as knowledge acquisition and the use of deep-learning strategies (Cano 2005). This positive dissonance is explained by characteristics of the learning environment that encourage students to develop a deep-learning approach. These research results, however, refer to traditional learning environments. They need to be verified in digital learning environments. 
(4.2) Conceptions of knowledge and knowing. Hofer (2004), Hofer and Pintrich (1997) developed a model that organizes epistemic beliefs in four dimensions, each seen as a continuum between two poles: the certainty of knowledge, ranging from definitive to evolutionary; the simplicity of knowledge ranging from individual concepts added one to another, to concepts seen to be interrelated; the source of knowledge, ranging from it being transmitted by an external authority, to it being produced by the person him or herself; the justification of knowledge, ranging from it being due to an authority, to it resulting from proof via a rigorous procedure. Automatically activated, epistemic beliefs would influence the goals constructed by the learner, the metacognitive processes and the choice of learning strategies (Muis 2007). The learner not only makes judgments about learning (Do I know?), but also makes what could be called epistemic judgments: How do I know? (Hofer 2004). The importance of these judgments can be seen in the trivialization of internet search, where queries using Google are in most cases the first step of a literature search (Biddix et al. 2011). The learner is confronted with a multitude of information sources, the reliability of which needs to be assessed. In this regard, (Bråten et al. 2005: 154) note that "in open and global information networks, anyone can publish anything, and the difficult task of checking the relevance and accuracy of information traditionally done by publishers, is now transferred to the students themselves". Finally, the analysis in terms of structural equation modelling carried out by Cano (2005) in a survey of 1600 Spanish students confirmed the direct and indirect influence (via learning approaches) of epistemic beliefs on school performance.

(5) Personality characteristics. One of the most influential characterisations of personality is the 'Big Five' model (Costa and McCrae 1992), so called because it organises personality in five traits: extraversion (active, sociable versus silent, shy); pleasantness (nice, cooperating versus nasty); conscientiousness (meticulous, applied versus disordered, distracted); emotional stability or neuroticism (calm, relaxed versus anxious, irritable); openness to experience (openness, curiosity versus conformity, conventional). In a research in the UK with Bachelor students, (Chamorro-Premuzic and Furnham 2008) observed that conscientiousness, and to a lesser extent openness to experience, have a significant impact on academic success. The recent meta-analysis of the psychological correlates of academic achievement conducted by Richardson et al. (2012) confirms that conscientiousness is significantly associated with academic achievement. In contrast, openness to experience does not seem to exercise significant influence. However, to our knowledge these features have not been linked to learning outcomes such as "the disposition to understand for oneself' (Entwistle and McCune 2013). In conclusion, as far as characteristics of students are concerned, it seems necessary to consider a whole range of features related to previous training experience, and the level of knowledge acquired to enter the program. This level can be assessed in various ways on the basis of past academic experience or, more specifically, via an initial assessment of knowledge about the area to be learnt. In addition, the impact of epistemic beliefs and conceptions of learning on the learning process now seems sufficiently documented through research for us to include them. With regard to 
personality characteristics, the results are more open to debate. What might appear as a personality characteristic influencing learning outcomes, namely conscientiousness, may turn out to be process variables. Being meticulous and focused on the goal could well be the effect of specific control strategies, called volitional strategies (or action control strategies) rather than the effect of personality characteristics. This is the conclusion reached by the recent meta-analysis of (Richardson et al. 2012). Eventually, two types of student population coexist in university programs: students coming directly from secondary education and adults returning to their studies. The previous learning experiences of the latter and the knowledge they have acquired, as well as their motives to engage in a new teaching program (Vertongen et al. 2009), are probably not without effect on their conceptions of learning and knowledge, as well as on their perceptions of the digital learning environment. These characteristics are likely to influence the learning outcomes. For quality management, a first question would be: how does HE and particularly new offers such as MOOCs do take into account students individual characteristics?

\section{Describing and Understanding the Role of the Teaching and Learning Environment}

The learning environment (seen as incorporating the learning objectives, the means and methods of instruction, the methods of assessment, the peers and teachers, the physical infrastructure), sometimes called the 'teaching context' (Biggs 2003) or 'teaching-learning environment' (Entwistle 2011), is found to affect how studentsaccording to their individual characteristics_-go about their studying and eventually explain quality learning outcomes. However, proposals by researchers for specific characteristics of these environments and how they should be structured to achieve such effects are fragmented, in that they are associated with particular features, or are hypothetical. This problem has been addressed in research on self-regulated learning. Several researchers, on both sides of the Atlantic, have been interested in existing interactions between the learning environment and self-regulated learning (Carré and Moisan 2002; Hiemstra 2000; Straka 2000). They have shown the influence of pedagogical control of the educational environment on the self-regulation of learners, while highlighting some personal characteristics that play a mediating role (characterizing the student-environment interaction), especially the feeling of self efficacy. The results of these studies, as well as research of the co-authors of this chapter (Cosnefroy and Jézégou) on the relationship between the environment and the learner will be considered. Furthermore, in the field of higher education, there is little research about specific forms of hybrid or digital learning environments in HE. When it comes to studying the role of the characteristics of these environments, the aspects most often selected refer to the technical and instructional design, content and methods of teaching and assessment, and less 
frequently the learning activities proposed and the discussion or exploration in these environments (Ellis and Goodyear 2010). These research works did not attempt to represent specific configurations formed by the articulation of these characteristics, or to formalize the interactions between these environmental characteristics and those of the students, or the effects of these interactions on learning. However, the most significant work has been done in the $\mathrm{ETL}^{3}$ project (Enhancing Teaching-Learning environments led by the University of Edinburgh). This project has highlighted many 'good practices' in relation to teaching specific disciplines or those that are common to several disciplines (Hounsell et al. 2005). It does not, however, propose a validated framework for describing specific configurations formed by the articulation of these dimensions and their effects on learning. In addition, it does not focus specifically on digital learning environments. HY-SUP Project (describing hybrid learning environments and understanding their effects ${ }^{5,6}$ ) fills this gap by specifically studying digital learning environments (hybrid, blended or at a distance). As already mentioned, the vast majority of the scientific literature devoted to hybrid learning environments is made up of satisfaction surveys of learners. Prior to HY-SUP, some specific research: e.g. (Peraya and Campion 2007; Charlier et al. 2006b; Docq et al. 2008) led to the identification of several potential effects on learning experienced by participants, on their identity dynamics and social interactions, and on the emergence of communities of practice. However, no large-scale research had answered the central question as to the effect of such digital learning environments on the quality of student learning, in particular. To validly answer this question, it was first necessary to characterize these environments based on dimensions such as: the forms of mediation and mediatisation; the articulation of the educational phases both in face-to-face and distance activities; the nature of human support; or contextual aspects such as the type of training, the number of students or educational practices (Peraya et al. 2014). Researchers in the HY-SUP project carried out research adopting a mixed-method approach in several studies (pilot study questionnaire: 174 teachers; large-scale study questionnaire: 179

\footnotetext{
${ }^{3}$ http://www.etl.tla.ed.ac.uk//docs/ETLfinalreport.pdf.

${ }^{4}$ The authors wish to thank the partners of the European HY-SUP project (DG. Education and Culture. Life Long Learning Programme) coordinated by the University Claude Bernard Lyon 1 (E. Bettler) and the University of Geneva (N. Deschryver). This project associated researchers and teachers from the universities of Fribourg (S. Borruat, B. Charlier, A. Rossier), Geneva (N. Deschryver, C. Peltier, D. Peraya, A. Ronchi et E. Villiot-Leclercq), Louvain-La-Neuve (F. Docq, M. Lebrun et C. Letor), Lyon (C. Batier et C. Douzet), Luxembourg (R. Burton et G. Mancuso) and Rennes 2 (G. Lameul, C. Morin).

${ }^{5}$ This synthesis is grounded on (Peraya et al. 2014).

${ }^{6}$ The French speaking reader will note that we have chosen, in all our publications, to translate the French expression 'dispositif' by the English term 'environment'. The term 'dispositif' does not have a satisfactory translation in English. We thank the informed reader for his or her understanding. A history of use of the two terms and their various interpretations would have been out of place here, given the limited number of pages. This presentation can be read in French in Charlier (2014, to be published).
} 
teachers and 456 students, and 80 interviews with 60 teachers and with 20 institutional managers) around three central questions:

- What are the characteristics of the existing environments?

- Depending on the type of hybrid learning environment, are there perceived effects on student learning and on the professional development of teachers?

- To what extent can the development of certain environments be associated with organizational characteristics of the universities?

Concerning the first issue, the major empirical results are, on the one hand, the identification of fourteen components, derived from statistical analysis (Burton et al. 2014) to differentiate hybrid learning environments and, on the other hand, a typology of six types of environments described and illustrated by (Lebrun et al. 2014). Note that the descriptions produced, exploiting both quantitative and qualitative data from different studies, are an excellent illustration of the relevance of a mixed methodological approach. It should however be noted that the components describing the openness of learning environments, that proved particularly relevant, deserve to be explored in more depth using recent work by Jézégou. The main contribution of her work is to propose a theory of the openness of teaching as well as modelling presence, especially in e-learning. Research carried out on openness led to a theoretical basis for the concept and to its definition in terms of the learner's freedom of choice to organize his or her own learning situations (Jézégou 2005). It also led to the development of GEODE (Jézégou 2010), an instrument used to assess the degree of openness of a digital learning environment (including the degree of openness of the spatiotemporal, pedagogical and mediated communication components). This instrument has been validated empirically. As for presence, research shows it is the result of some form of collaborative social interaction between learners and between the teacher and learners within a digital communication space. Such a presence at a distance promotes the emergence and development of a learning community with the resulting individual and collective construction of knowledge. Work on the dynamic modelling of that presence helped characterize collaborative interactional processes at work in each of the three dimensions of presence at a distance (Jézégou 2012a): (1) socio-cognitive (2) socio-affective and (3) pedagogical. An instrument to assess the degree of presence in e-learning (GEPE) was recently developed and its internal validity verified. Empirical research conducted by Jézégou has identified the influence (independently or together) of two environmental dimensions - the degree of openness (as theorized) and the degree of presence (as modelled) - on the self-directed learning of adults in the context of e-learning, blended learning and MOOC. It has demonstrated the role of several personal characteristics of a motivational nature in the interplay of influence observed. These are the need for self-determination, structure, competence and social affiliation. These empirical studies have also shown that the learners' perception of openness or, in other words, their perception of the degree of freedom of choice offered by the established educational environment, has an influence on the self-regulation strategies implemented. They have also helped describe and understand the self-regulation 
strategies implemented by learners to construct an optimal learning environment, incorporating established educational factors as well as psychosocial factors. The results of this research program were taken into account in developing a research proposal (INTENS), which offers an opportunity to pursue that work. Given this perspective, the proposed research will include a comparative understanding, in a model coupling 'degree of openness' and 'degree of presence', of the effects of these two environmental dimensions on student's self-regulated learning in both hybrid and distance learning, and the role played by learners' perception of these degrees of openness and presence. For policy makers, tools are now available to describe and understand digital learning environments, and to select and evaluate those which would have better effect on the development of autonomous students and deep learning.

\section{Understanding Interactions Between Students and Their Environment}

Constructs characterizing interactions between students and learning environments, both in terms of representations and behaviours, have been the subject of much research.

(1) Self-efficacy is a contextual judgment that anticipates one's ability to achieve a certain level of performance in a given situation (Bandura 1986). This is typically a product of the interaction between the subject and his or her environment. It has been identified as one of the variables that have the greatest impact on the learning process (Sitzmann and Ely 2011). It leads to the use of more efficient cognitive strategies, to improved assessment of performance, to undertaking more challenging activities, to an increase in the effort and time spent studying, to increased resilience confronted with difficulties, and to a diminution of anxiety, which all ultimately lead to improved performance (Schunk 1991; Schunk and Pajares 2005; Zimmerman 1989, 2000). Two main factors are involved in the construction of self-efficacy: the success experienced in previous academic experiences, and social persuasion, that is to say, the judgment of others (Schunk 1991; Schunk and Pajares 2005; Zimmerman 1989, 2000).

(2) The orientation of goals. Over the past 20 years, there has been a revival of the theory of achievement goals that could be translated more precisely by competence goals, as they reflect what competence means for the learner. Several studies have examined the relationship between academic performance and three achievement goals (see the recent meta-analysis of (Wirthwein et al. 2013): learning goals (or mastery); performance approach goals (goals seeking to prove competence by outperforming others); avoidance approach goals (goals seeking to avoid failure). More recently, the theory has been enriched by a fourth and a fifth goal (Elliot 1999; Elliot et al. 2011; Pintrich 2000). Research conducted with college students showed that learning goals have effects on the learning approaches chosen, but have 
no tangible impact on academic performance. Of particular note is that longitudinal research conducted by Harackiewicz et al. (1997, 2000), Barron and Harackiewicz (2001), using self-reported questionnaires, shows the differentiating effects of learning goals and performance approach goals. The former are strongly correlated with the implementation of deep-learning strategies and the development of interest, but only the latter have a significant effect on performance. At first glance surprising, these results can be explained if one takes into account the nature of the assessment proposed to students, which is mostly multiple-choice. As for avoidance approach goals, they would have a moderate negative effect on academic performance. In drawing up the methodology for researches, but also for quality evaluation, these results underline the need to take into account the nature of the assessment proposed in the various courses to be analysed so as to ascertain the possible influence of the goals on learning outcomes.

(3) Self-regulation strategies. The control of learning activity takes place by means of self-regulation strategies, namely general rules of action that guide the activity in order to make it optimal with respect to the goals fixed. It is through the use of various self-regulation strategies that the learner takes control of his or her learning. If the learning strategies and metacognitive strategies have been the subject of numerous studies (Romainville 1993; Vermunt 1998; Weinstein et al. 2000), the same cannot be said of volitional strategies or strategies to control action, aimed at sustaining motivation and effort. The latter, unlike the former, are not intended to act directly on the cognitive processes implemented to perform the task. Their purpose is to maintain engagement in the task, to protect the intention of learning and the continuity of action. These strategies have been particularly studied in the framework of research on self-regulated learning. Self-regulated learning refers to all processes by which subjects activate and maintain cognitions, affects and behaviours systematically oriented towards a goal (Schunk 1994). The aim of this research is twofold: to determine the psychological conditions of autonomy in learning, and to identify conditions that positively influence the development of autonomy. One of the basic assumptions shared by all researchers in this field is that the on-going state of autonomy is not to be taken for granted. Claiming that a learner is able to be independent does not mean he or she is autonomous in all circumstances. It depends on the conditions and the context in which learning takes place on the one hand, and the content to be learnt on the other. It is precisely this variability of the nature of self-regulation and the influence of context that must be examined by research on self-regulated learning (Boekaerts 1992, 1996; Pintrich 2000; Zimmerman 2000). Self-regulatory processes are considered as mediators between personal characteristics and those of the environment on the one hand, and learning outcomes on the other. Note, however, that the principle of contextualization of self-regulation has produced very little research about the genesis and implementation of self-regulatory strategies themselves. The gap is evident between the theoretical framework and research results (Cosnefroy 2009). Once engaged in a learning activity, effort is required to ensure continuity of action by preventing or combating distractions and difficulties. Setting a challenging goal is one thing, reaching it is another. Theoretically, two distinct sets of processes are considered: 
motivation, which prepares decisions and promotes the intention to learn (goal setting); volition, which protects the implementation of these decisions (goal attainment) (Corno 2001). Motivation and volition are two components of a larger entity which, following (Reuchlin 1999), one might call conation, a term designating factors that govern the orientation of both behaviour and its control. Knowledge concerning the nature and use of volitional strategies and their conditions of validity remains incomplete. Some researchers have sought to account for self-regulation strategies used by learners, including (Corno 2001; Pintrich 2000; Wolters 2003; Zimmerman 1989, 2000; Zimmerman and Martinez-Pons 1986). Based on these partial syntheses, (Cosnefroy 2010, 2011, 2013), set up a new taxonomy of self-regulation strategies including volitional strategies. In this taxonomy volitional strategies are categorized by two sub-components: control of the inner states and control of the learning environment. The former refer to the control of motivation (by sustaining the learning-task value and learner's self-efficacy) and emotions, more specifically negative emotions such as shame, anger, helplessness and anxiety. Strategies devoted to the control of the learning context are threefold: (1) Environment structuring (e.g. arranging a quiet study area); (2) resources enhancement (e.g. seeking help); (3) time management (e.g. allocation of time and setting of priorities). Among the latter strategies, time management skills are probably paramount, insofar as research has shown they are lacking for most higher education students (Meer et al. 2010). This new taxonomy could be used to analyse the impact of these strategies on learning outcomes.

(4) Approaches to learning. Student approaches to learning are strongly related to students' conceptions of learning. However, they don't describe personal characteristics, but rather ways of learning that depend on interactions with the learning environment (Cano 2005; Entwistle 2009). Research on approaches to learning carried out in learning and teaching in Higher Education over the last 40 years have highlighted the relationships between student characteristics (age, gender, personal story, training, previous experience) and their conceptions of learning, approaches to learning and learning orientations, as well as the influence of contextual factors (influence of peers, teachers, learning environments and institutional strategy) and of student perceptions of this context (Biggs 2003; Entwistle 2003a, b; Pintrich 2003; Ramsden 2003; Richardson 2005; Saljö 1979a, b). Among the contextual factors, assessment deserves special consideration. Entwistle has introduced the strategic approach (i.e. using surface or deep strategies according to task requirements) because assessment strongly affects studying (Entwistle and McCune 2004). More recently, (Ellis and Goodyear 2010) have examined student experiences of learning through discussion and through inquiry in face-to-face and online situations. The authors have found correlations between elements of the experience of learning (conceptions, approaches, and perceptions of the environment) and performance outcomes. Their results confirm the relevance of our research programme: "Students' experiences of e-learning, need to be understood in relation to the whole experience of learning, whether at course or whole degree level. Clearly e-learning is part of a broader experience of learning. Its association with other parts of the 
experience and the implications of these associations are only just beginning to be understood". (p. 71).

(5) Perception of the environment. Relationships between student's individual characteristics, such as their conceptions of learning and their perceptions of the learning environment, are represented in earlier studies (Meyer 1991) by the term 'study orchestration'. Such 'orchestration' could be either harmonious (i.e. combinations of deep approaches and positive perceptions of learning and teaching environment) or dissonant (Meyer and Vermunt 2000). For the same environment, the HY-SUP project (See. Supra) also showed the diversity of student perceptions, as well as a positive correlation between these perceptions, learning approaches and perceived effects on learning. The same goes for the work of Jézégou on student perception of openness and presence characterised by these environments. As a result, the perception of the digital learning environment will be considered. In conclusion, the interactions between the variables described above have rarely been studied systematically. This is not surprising since they correspond to different research paradigms. Thus, research on self-regulated learning emphasises that the learning processes cannot be understood if they are reduced to the cognitive dimension. They have therefore sought to document the motivational aspects of learning and volitional behaviour. Despite the fact that cognitive and metacognitive strategies are constantly cited as essential for successful self-regulation, research on approaches and conceptions of learning are rarely evoked in work on self-regulation strategies (Entwistle and McCune 2013). There's a need to bridge the gap between the two research traditions. The relationship between achievement goals and learning approaches has been extensively studied, however little work has been done on the impact of performance goals on volitional strategies. With the notable exception of (Pintrich 2000), the theory of achievement goals is not a major theoretical reference model for self-regulated learning (i.e. Corno, Boekaerts, Winne, Pintrich, Zimmerman). We suggest to systematically examining the interactions of these sets of variables in the context of a digital learning environment in the broad sense defined above. Finally, the evaluation methods affect the choice of learning approaches and the impact of these approaches on performance (deep strategies not necessarily leading to better performance). Taking this variable into consideration is particularly important, as forms of learning assessments often have different characteristics in distance learning and hybrid courses. For policy makers and quality management, learning assessment methods are good indicators of teaching quality.

\section{Evaluating Learning Outcomes}

Two types of data can be studied to assess learning outcomes: objective data and subjective data (perceptions).

Objective data. In addition to exam marks (Galand and Frenay 2005), several indicators have been investigated. For example, effective learning can be analysed in terms of quantity and quality according to the 'Structure of Observed Learning 
Outcomes' (SOLO) taxonomy (Biggs and Tang 2007). Several learning levels are defined, ranging from a quantitative phase (integrated information) to a qualitative phase (level of linkages between concepts). In the ETL (Enhancing Teaching-Learning Environments) project, another concept has been developed to represent the quality of learning in different disciplines: WTPs (ways of thinking and practising in the subject) (Entwistle 2003a). Finally, more recently, the OECD project, AHELO set out to develop a: "direct evaluation of student performance at the global level and valid across diverse cultures, languages and different types of institutions." The results of the feasibility study were published in three volumes (OECD 2013).

Subjective data. Stories of learning experiences are frequently used as well as the expression of the student's future learning projects. This approach derives from a representation of learning as essentially experiential (Bourgeois 2009). This interest in "the experience of learning" has led authors like (Saljö 1979a, b) and (Marton et al. 1993) to study approaches and conceptions of student learning. However, more recently, (Entwistle and McCune 2013) proposed a new concept, "the disposition to understand for oneself' as a potential product of student learning, particularly in relation to digital learning environments. The authors define this concept as consisting of four dimensions: "The knowledge and ability required to develop and use understanding in adopting a reasoned stance to complex issues (ability); A continuing desire to adopt effortful, deep approaches across a wide range of contexts (willingness); A readiness to monitor and discuss the process of learning and developing understanding within the discipline (awareness of process); An alertness to opportunities to develop understanding further and to apply it in academic and professional contexts (sensitivity to context)" (p. 305). In this regard, the authors emphasize the need for future research. "Good evidence that the disposition to understand for oneself can be effectively developed would require studies that follow students throughout, and beyond, a programme of study, but such research has yet to be carried out" (p. 306).

\section{Conclusion}

The state of the art and the co-authors of this chapter justify and demonstrate the feasibility of an ambitious research project to answer the following two questions: 1. How do student characteristics and those of digital learning environments interact? 2. What are the configurations emerging from these interactions that can lead to quality learning? The conceptual framework that will support the investigation is presented in the Fig. 2.

Mixed methods longitudinal research realised with several HE Education programs will be necessary to answer to the research questions. We won't develop here in details the methodological design. This design innovates methodologically in that it integrates the collection and analyses of data of both student behaviour and representations as part of longitudinal research covering a large number of 


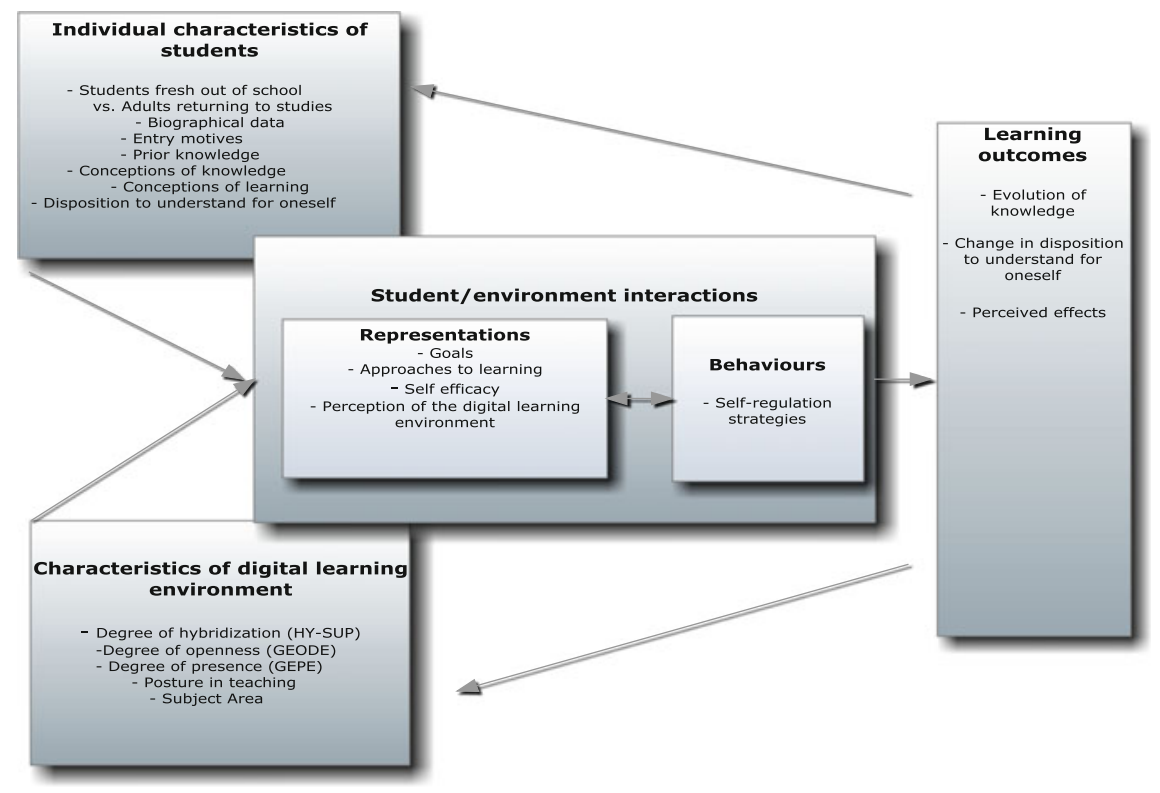

Fig. 2 INTENS: initial conceptual framework

programs. The work will enable the validation of data collection instruments and measurement protocols, while contributing to the production and validation of our conceptual framework and theoretically supported knowledge.

From a pragmatic point of view, as we have already done in earlier work, we aim to produce knowledge that can serve directly to inform action and aid decision-making in the field (program evaluation, designing environments, support, improvement of learning achieved, etc.). The analyses produced, the models developed could serve to decode the complexity of hybrid or remote, digitally-based learning environments in higher education.

The development of MOOCs (Massive Open Online Courses), which has sparked so much scientific and educational debate, could be clarified by the results. One of the most important impacts for higher education will be the identification of conditions necessary to provide digital learning environments for students that involve them further in their training. For policymakers and teachers, the results will provide resources to improve methods of design and quality assessment for educational programs.

In advance, considering each part of our model, we could already suggest criteria to be considered for decision making and quality management:

1. Individual characteristics of students

The quality of learning environments and of teaching programs cannot be assessed without considering individual characteristics of students. Thus neither unique, nor ideal solution, even if they are supported by the more recent 
technologies, does exist. Thus, the first criterion would be the extent to which individual characteristics of the students are taken into account.

2. Characteristics of digital learning environment

Digital learning environment can be described in their complexity. Recent research results provide tools that enable to describe, compare and examine their effects. Thus, a second criterion would be to examine how quality management systems integrate such tools.

3. Student Environment-Interaction

More complex is to take into account the complex dynamic of learning appearing through the interactions between students and their learning environment. This plaid for formative quality management systems that offer tools to students, teachers and designers to express their goals, their own representations of learning environment, and to have an impact on it. Thus, a third criterion would be the extent to which actors are enabled to act on their own environment.

4. Learning outcomes

Learning outcomes are often evaluated through the satisfaction of students or through the assessment results without taking into account Value Added Models. More sophisticated models, such as the one proposed by the project AHELO, could be used. Furthermore, new learning outcomes, such as the disposition to understand for oneself, could be considered. Thus, a fourth criterion would be the quality and complexity of quality learning assessment.

Eventually, even if researches provide more tools and integrated knowledge to make HE more intelligible for all, more efforts are still needed, and a last recommendation would be to support further researches that are based on rigorous state of the arts and conducted by interdisciplinary teams.

Open Access This chapter is distributed under the terms of the Creative Commons Attribution Noncommercial License, which permits any noncommercial use, distribution, and reproduction in any medium, provided the original author(s) and source are credited.

\section{References}

Atzamba, H., \& Petroff, C. (2003). Etudiants 2001. Genève: Université de Genève, Département de sociologie.

Bandura, A. (1986). Social fondations of though and action: A social cognitive theory. Englewood Cliffs, USA: Prentice-Hall.

Barron, K. E., \& Harackiewicz, J. M. (2001). Achievement goals and optimal motivation: Testing multiple goal models. Journal of Personality and Social Psychology, 80(5), 706.

Bell, B. S., \& Kozlowski, W. J. (2002). Goal orientation and ability: Interactive effects on self-efficacy, performance, and knowledge. Journal of Applied Psychology, 87(3), 497.

Biddix, J., Chung, C. J., \& Park, H. W. (2011). Convenience or credibility? A study of college students online research behavior. Internet and Higher Education, 14, 175-182.

Biggs, J. (2003). Teaching for quality learning at university. Buckingham: The Society for Research into Higher Education and Open University Press. 
Biggs, J., \& Tang, C. (2007). Teaching for quality learning at university. What the student does (3th ed.). Berkshire: McGraw-Hill \& Open University Press.

Boekaerts, M. (1992). The adaptable learning process: Initiating and maintaining behavioural change. Applied Psychology: An International Review, 41(4), 377-397.

Boekaerts, M. (1996). Personality and the psychology of learning. European Journal of Personality, 10.

Bourgeois, E. (2009). Apprentissage et transformation du sujet en formation. In J. M. Barbier, E. Bourgeois, G. Chapelle \& J. C. Ruano-Borbalan (Eds.), Encyclopédie de la Formation (pp. 3169). Paris: Presses Universitaires de France.

Bråten, I., Strømsø, H., \& Samuelsteren, M. (2005). The relationship between internetspecific epistemological beliefs and learning within internet technologies. Journal of Educational Computing Research, 33(2), 141-171.

Burton, R., Mancuso, G., \& Peraya, D. (2014). Une méthodologie mixte pour l'étude des dispositifs hybrides: quelle méthodologie pour analyser les dispositifs hybrides de formation? Éducation \& Formation, e-301.

Cano, F. (2005). Epistemological beliefs and approaches to learning: Their change through secondary school and their influence on academic performance. British Journal of Educational Psychology, Blackwell Publishing Ltd.

Carré, P., \& Moisan, A. (Eds.). (2002). La formation autodirigée: aspects psychologiques et pédagogiques. Paris: L'Harmattan.

Chamorro-Premuzic, T., \& Furnham, A. (2008). Personality, intelligence and approaches to learning as predictors of academic performance. Personality and Individual Differences, 44, 1596-1603.

Charlier, B., Deschryver, N. \& Peraya, D. (2006a). A la recherche des effets des dispositifs hybrides. Distances et savoirs, 4(4), 469-496.

Charlier, B., Nizet, J. et Van Dam, D. (2006b). Voyages au pays de la formation des adultes: dynamiques identitaires et trajectoires, sociales. Paris: L'Harmattan.

Cisel, M., \& Bruillard, E. (2013). Chronique des MOOC. Rubrique de la Revue STICEF, 19.

Corno, L. (2001). Volitional aspects of self-regulated learning. Self-regulated learning and academic achievement: Theoretical perspectives, 2, 191-225.

Cosnefroy, L. (2009). L'apprentissage autorégulé: les effets conjoints de la métacognition et de la motivation. Note de synthèse pour l'habilitation à diriger les recherches: Université Paris Ouest La Défense.

Cosnefroy, L. (2010). L'apprentissage autorégulé: perspectives en formation d'adultes. Savoirs, 2 (23), 9-50.

Cosnefroy, L. (2011). L'apprentissage autorégulé: entre motivation et cognition. France: Presses Universitaires de Grenoble.

Cosnefroy, L. (2013). Autonomie et formation à distance. Recherche \& formation, 1, 111-118.

Costa, P. T. J., \& McCrae, R. R. (1992). Revised NEO personality inventory (NEO-PI-R) and NEO five-factor inventory (NEO-FFI) manual. Odessa, FL: Psychological Assessment Resources.

Cross, K. P. (1981). Adults as learners. Increasing participation and facilitating learning. San Francisco: Jossey-Bass.

Daniel, J. (2012). Making sense of MOOCs: Musings in a maze of myth, paradox and possibility. Journal of interactive media in Education.

Deschryver, N. (2008). Interaction sociale et expérience d'apprentissage en formation hybride. Université de Genève, Genève. Retrieved from http://archive-ouverte.unige.ch/unige:21861

Docq, F., Lebrun, M., \& Smidts, D. (2008). À la recherche des effets d'une plateforme d'enseignement/apprentissage en ligne sur les pratiques pédagogiques d'une université: premières approches. Revue Internationale des Technologies en Pédagogie Universitaire, 5(1), $45-57$.

Elliot, A. (1999). Approach and avoidance motivation and achievement goals. Educational Psychologist, 34(3), 169-189.

Elliot, J. A., Murayama, K., \& Pekrun, R. (2011). A $3 \times 2$ achievement goal model. Journal of Educational Psychology, 103(3), 632. 
Ellis, R., \& Goodyear, P. (2010). Students' experiences of e-learning in higher education. London: Routledge.

Entwistle, J. N., \& McCune, V. (2004). The conceptual bases of study strategy inventories. Educational Psychology Review, 16, 325-346.

Entwistle, N. (2003a). Concepts and conceptual frameworks underpinning the ETL Project. Edinburgh: School of Education, University of Edinburgh.

Entwistle, N. (2003b). Enhancing teaching-learning environments to encourage deep learning. In E. Decorte (Ed.), Excellence in higher education (pp. 83-96). London: Portland Press.

Entwistle, N. (2009). Teaching for understanding at university. New York: Palgrave Macmillan.

Entwistle, N. (2011). Cultivating the disposition to understand in 21 st century university education. Learning and Individual Differences, 21, 303-310.

Entwistle, N., \& McCune, V. (2013). The disposition to understand for oneself at university: Integrating learning processes with motivation and metacognition. British Journal of Educational Psychology, Blackwell Publishing Ltd., 2013(83), 267-279.

Galand, B., \& Frenay, M. (Eds.). (2005). L'approche par problèmes et par projets dans l'enseignement supérieur. Louvain-La-Neuve: Presses Universitaires de Louvain.

Grover, S., Franz, P., Schneider, E. and Pea, R. (2013) The MOOC as distributed intelligence: Dimensions of a framework for the design and evaluation of MOOCs. In Proceedings of the 10th International Conference on Computer Supported Collaborative Learning, June 16-19, Madison, WI.

Harackiewicz, J. M., Barron, K. E., Carter, S. M., Lehto, A. T., \& Elliot, A. J. (1997). Predictors and consequences of achievement goals in the college classroom: Maintaining interest and making the grade. Journal of Personality and Social Psychology, 73(6), 1284.

Harackiewicz, J. M., Barron, K. E., Tauer, J. M., Carter, S. M., \& Elliot, A. J. (2000). Short-term and long-term consequences of achievement goals: Predicting interest and performance over time. Journal of Educational Psychology, 92(2), 316.

Hidi, S., \& Renninger, K. A. (2006). The four-phase model of interest development. Educational Psychologist, 41(2), 11-127.

Hiemstra, R. (2000). Self directed learning: The personal responsibility model. In G. Straka (Ed.), Conceptions of self-directed learning: Theoretical and conceptionnal considerations (pp. 93108). Berlin: Waxmann.

Hofer, B. (2004). Epistemological understanding as a metacognitive process: Thinking aloud during online searching. Educational Psychologist, 39(1), 43-55.

Hofer, B., \& Pintrich, P. (1997). The development of epistemological theories: Beliefs about knowledge and knowing and their relation to learning. Review of Educational Research, 67, 88-140.

Hounsell, D., Entwistle, N., Meyer, E., Beaty, E., Tait, H., Anderson, C., \& Land, R. (2005). Enhancing teaching-learning environments in undergraduate courses. Retrieved: ETL Project-Final Report.

Jézégou, A. (2005). L'ouverture en formation: libertés de choix et autodirection de l'apprenant.

Jézégou, A. (2010). Community of inquiry in e-learning. A critical analysis of Garrison and Anderson model. Journal of Distance Education, 24, 12-29. Retrieved from http://www.jofde. ca/index.php/jde/article/view/707

Jézégou, A. (2012a). Presence in e-learning: Theoretical model and perspectives for research. Journal of Distance Education/Revue de l'Education à Distance, 26. Retrieved from http:// www.jofde.ca/index.php/jde/article/view/809

Lebrun, M., Peltier, C., Peraya, D., Burton, R., \& Mancuso, G. (2014). Un nouveau regard sur la typologie des dispositifs hybrides de formation: proposition méthodologiques pour identifier et comparer ces dispositifs. Éducation \& Formation, e-301.

Marton, F., Dall'Alba, G., \& Beaty, E. (1993). Conceptions of learning. International Journal of Educational Research, 19(3), 277-300.

Meer, J. V. D., Jansen, E., \& TorenbeeK, M. (2010). It's almost a mindset that teachers need to change: First-year students' need to be inducted into time management. Studies in Higher Education, 35(7), 777-791. 
Meyer, J. H. F. (1991). Study orchestration: The manifestation, interpretation and consequences of contextualised approaches to studying. Higher Education, 2(3), 297-316.

Meyer, J. H. M., \& Vermunt, J. D. (2000). Special issue-dissonant study orchestration in higher education manifestation and effects-Introduction.

Morlaix, S., \& Suchaut, B. (2012). Les determinants sociaux, scolaires et cognitifs de la réussite en première année universitaire. Revue Française de Pédagogie, 180, 77-94.

Muis, K. R. (2007). The role of epistemic beliefs in self-regulated learning. Educational Psychologist, 42(3), 173-190.

OECD. (2013). Assessment of higher education learning outcomes. AHELO: Feasibility study report (Vol. 3). Further insights, Retrieved from http://www.oecd.org/education/skills-beyondschool/AHELOFSReportVolume3.pdf

Peers, I., \& Johnston, M. (1994). Influence of learning context on the relationship between A-level attainment and final degree performance. A meta-analytical review. British Journal of Educational Psychology, 64, 1-18.

Peraya, D., \& Campion, B. (Eds.). (2007). L'analyse des dispositifs hybrides: les effets d'un changement d'environnement virtuel de travail: d'un site Web à la plateforme Claroline. Louvain la Neuve: Presses universitaires de Louvain.

Peraya, D., Charlier, B., \& Deschryver, N. (2014). Etudier les dispositifs hybrides. Pourquoi ? Comment ? In N. Deschryver \& B. Charlier (Eds.), Les dispositifs hybrides dans l'enseignement supérieur: questions théoriques, méthodologiques et pratiques (Vol. e-301). Education \& Formation.

Pintrich, (2003). Student motivation and self regulation in the college classroom: Basic principles and implications for the design of instruction. In E. Decorte (Ed.), Excellence in Higher Education (Vol. 82, pp. 97-109). London: Portland Press.

Pintrich, P. (2000). The role of goal orientation in self-regulated learning. In M. Bœkærts, P. Pintrich, \& M. Zeidner (Eds.), Handbook of self-regulation (pp. 451-502). San Diego, Ca: Academic Press.

Ramsden, P. (2003). Learning to teach in higher education. London: Routledge Falmer.

Renninger, K. A., Renninger, K. A., Bachrach, J., \& Posey, S. (2012). Learner interest and achievement motivation. In M. Maehr, S. Karabenick, \& T. Urdan (Eds.), Advances in motivation and achievement: Social psychological perspective (Vol. 15, pp. 461-491). Bingley (UK): Emerald.

Reuchlin, M. (1999). Evolution de la psychologie différentielle. Paris: PUF.

Richardson, J. T. E. (2005). Students' approaches to learning and teachers' approaches to teaching in higher education. Educational Psychology, 25(6), 673-680.

Richardson, M., Abraham, C., \& Bond, R. (2012). Psychological correlates of university students' academic performance: A systematic review and met-analysis. Psychological Bulletin, 138(2), 353-387.

Romainville, M. (1993). Savoir parler de ses méthodes: métacognition et performance à l'université. De Boeck Supérieur.

Saljö, R. (1979a). Learning in the learner's perspective: II. Difference in awareness. University of Göteborg: Report from the Institute of Education.

Saljö, R. (1979b). Learning in the learner's perspective. I. Some common-sense conceptions. ERIC Clearinghouse.

Schunk, D. (1994). Self-regulation of self-efficacy and attributions in academic settings. In D. Schunk \& B. Zimmerman (Eds.), Self-regulation of learning and performance: Issues and educational applications (pp. 75-99). NJ Lawrence Erlbaum: Hillsdale.

Schunk, D. H. (1991). Self-efficacy and academic motivation. Educational Psychologist, 26(3-4), 207-231.

Schunk, D. H., \& Pajares, F. (2005). Competence perceptions and academic functioning. In E. J. Andrew \& D. S. Carol (Eds.), Handbook of competence and motivation (pp. 85-104).

Sitzmann, T., \& Ely, K. (2011). A meta-analysis of self-regulated learning in work-related training and educational attainment: What we know and where we need to go. Psychological Bulletin, 137(3), 421-442. 
Straka, G. A. (2000). Conceptions of self-directed learning: Theoretical and conceptual considerations. LOS, learning organized self-directed research group. Munster: Waxmann.

Tinto, V. (1975). Dropouts from higher education: A theoretical synthesis of recent research. Review of Educational Research, 45, 89-125.

Vermunt, J. D. (1998). The regulation of constructive learning process. British Journal of Educational Psychology, 68, 149-171.

Vertongen, G., Bourgeois, E., Nils, F., Viron, F. D., \& Traversa, J. (2009). Les motifs d'entrée en formation des adultes en reprise d'études universitaires. L'orientation scolaire et professionnelle, 38(1), 25-44.

Weinstein, C., Husman, J., \& Dierking, D. (2000). Self-regulation interventions with a focus on learning strategies. In M. Boekaerts, P. Pintrich, \& M. Zeidner (Eds.), Handbook of self-regulation (pp. 728-747). San Diego, CA: Academic Press.

Wirthwein, L., Sparfeldt, J. R., Pinquart, M., Wegerer, J., \& Steinmayr, R. (2013). Achievement goals and academic achievement: A closer look at moderating factors. Educational Research Review, 10, 66-89.

Wolters, C. A. (2003). Regulation of motivation: Evaluating an underemphasized aspect of self-regulated learning. Educational Psychologist, 38(4), 189-205.

Zimmerman, B. (1989). A social-cognitive view of self-regulated academic learning. Journal of Educational Psychology, 81(3), 329-339.

Zimmerman, B. (2000). Attaining self-regulation: A social-cognitive perspective. In M. Boekaerts, P. Pintrich, \& M. Zeidner (Eds.), Handbook of self-regulation (pp. 13-39). San Diego, CA: Academic Press.

Zimmerman, B. (2002). Efficacité perçue et autorégulation des apprentissages durant les études: une vision cyclique. In P. Carré \& A. Moisan (Eds.), La formation autodirigée. Aspects psychologiques et pédagogiques. Paris: L'Harmattan.

Zimmerman, B., \& Martinez-Pons, M. (1986). Development of a structured interview for assessing student use of self-regulated learning strategies. American Educational Research Journal, 23 (4), 614-628. 